\author{
Agnieszka Czyżak \\ Wydział Filologii Polskiej i Klasycznej \\ Uniwersytet im. Adama Mickiewicza w Poznaniu \\ e-mail: agaczyz@amu.edu.pl
}

\title{
Porządkowanie tekstowych przestrzeni biograficznych - wokół Ostatniego rozdania Wiesława Myśliwskiego
}

Twórczość Wiesława Myśliwskiego odbierana jest wielorako - jednak jej recepcja krytyczna przebiega pomiędzy dwoma biegunami: pełnej akceptacji dla prozy klasycznej, arcydzielnej, ważnej dla polskiej kultury oraz niechętnej nieufności wobec staroświeckich, jakoby anachronicznie skrojonych utworów. Jednym z powodów zarówno zachwytów, jak i wątpliwości są tekstowe strategie porządkowania świata, narracyjne gesty opanowywania zarażonej chaosem i rozpadem przestrzeni, a także kreacje bohaterów i ich znaczących biografii, dociążonych nadto symbolicznie - prowokujących do uniwersalnych odczytań i poszukiwania ponadjednostkowych wykładni pojedynczych losów postaci.

W Ostatnim rozdaniu porządkowanie staje się motywem przewodnim utworu, tematyzowanym nieustannie nadrzędnym zadaniem bohatera-narratora, który stale podkreśla:

robienie porządków stanowi w jakimś stopniu o naszym poczuciu istnienia. Porządkujemy, co tylko się da. Fotografie, listy, książki, dokumenty. Trudno by wymienić wszystko, co porządkujemy [...] każdy chcąc nie chcąc, staje przed koniecznością zrobienia porządku, choćby z grubsza, czy aby stworzyć przynajmniej pozory ${ }^{1}$.

\footnotetext{
1 W. Myśliwski, Ostatnie rozdanie, Kraków 2013, s. 17. W dalszej części artykułu lokalizacja cytatów z numerami stron według tego wydania.
} 
Główny bohater utworu snuje opowieść o swoim życiu, próbując je uporządkować według zapisanych w starym rozpadającym się notesie adresów osób $\mathrm{z}$ własnej przeszłości, których twarzy z reguły nie potrafi już sobie przypomnieć. Podejmuje swoistą walkę z zawartością owego notesu, będącego przedmiotem $\mathrm{w}$ istocie nierzeczywistym, bo zawierającym podobno nazwiska i adresy wszystkich spotkanych przez bohatera osób. Nadto zapisane w nim zostały także informacje "cudze", bo spisywane w młodości z kopert pożyczanych od znajomego listonosza - po to, by zapełnić puste wówczas kartki.

Przedzieranie się przez gąszcz zatartych zapisków, stanowiących po upływie lat puste znaki, staje się czynnością tyleż daremną, co pozbawioną jakiegokolwiek sensu. Bohater zaczyna działać w porządku alfabetycznym, ale już „przebrnięcie” przez nazwiska rozpoczynające się na literę " $\mathrm{A}^{\prime \prime}$ okazuje się zadaniem ponad siły. Jednocześnie narrator usiłuje określić przebieg i przemianę własnych relacji ze światem, który wkrótce będzie musiał opuścić. Spowiadając się z własnego życia, czyniąc rozmaite gesty pożegnania ujawnia przyczyny wcześniejszych wyborów - przede wszystkim ponawianej decyzji, by nigdy nie mieć własnego domu, by nigdzie nie zapuścić korzeni. To wizja specyficznej więzi ze światem, która ogranicza się do nieustannego ślizgania się po jego powierzchni. Elżbieta Rybicka, poszukując wspólnej płaszczyzny dla twórczości Kennetha White'a i Kazimierza Brakonieckiego, uznała, że jest nią „światowanie":

Dla poety szkocko-bretońskiego to poetyka otwartego świata, w którym każde miejsce jest miejscem otwartym. Dla poety warmińsko-mazurskiego rdzeniem światowania i światologii jest pochodzące z warmińskiej gwary słowo „światować", oznaczające tyle, co żyć. Dla Brakonieckiego „światowanie” bliskie jest metafizyce konkretu egzystencjalnego, wyczulenia na realność miejsca. Zmierza ono do otwarcia na świat, w którym zanika podział na to, co zewnętrzne, i to, co wewnętrzne ${ }^{2}$.

W takim ujęciu „światowanie” jest bliskie także Myśliwskiemu, który jako autor utworów prozatorskich sytuuje swoich bohaterów wobec określonych miejsc, jednocześnie ukazując ich symbiotyczne związki z przestrzenią która rozszerza się z każdym kolejnym utworem, nie przestając być przestrzenią własną, choć doświadczaną w wieloraki (także bolesny) sposób. Można uznać, że w przypadku autora Nagiego sadu droga twórcza prowadzi od wariantu Brakonieckiego ku rozpoznaniom White'a.

\footnotetext{
2 E. Rybicka, Geopoetyka: konstelacja i światowanie, w: Przestrzeń - literatura - doświadczenie. Z inspiracji geopoetyki, red. T. Gęsina, Z. Kadłubek, Katowice 2016, s. 11-12.
} 
„Światowanie” dla bohaterów Myśliwskiego to nie tylko życie jako czysta egzystencja, ale życie jako dopasowywanie się do przeznaczonego przez los miejsca w świecie. Więcej historii i pamięci u obu polskich autorów (niż u szkockiego wizjonera) wynika nie tyle ze skomplikowanych dziejów Polski w XX wieku - jak twierdzi Rybicka - ile z przywiązania wskazanych pisarzy do kreślenia dziejów wspólnoty, choćby były zaledwie dalekim, zatartym tłem wydarzeń. Z kolei więź z materią, widoczna u bohaterów Myśliwskiego, jest oczywistą konsekwencją osadzenia ludzkiej egzystencji w świecie. Zawsze istotna okazuje się też odpowiedź na pytanie, gdzie człowiek wiedzie swój żywot. Tadeusz Sławek twierdził z przekonaniem:

"Gdzie?" dąży zawsze do jakiegoś wskazania, i samo pytanie kreśli już domyślny pejzaż lub choćby tylko jeden ciemny punkt zakłócający bezmiar. "Gdzie?" jest sposobem radzenia sobie z bezmiarem [...] „Gdzie?" ratuje nas przed grozą. Nieustannie zatem powinniśmy pytać "gdzie?", przerażenie bowiem może kryć się nie tylko w ogromie kosmicznych odległości; może w każdej chwili wychynąć z pozornie dobrze znanych i znajomych miejsc ${ }^{3}$.

Nad grozą bycia w świecie i przerażeniem, jakie budzi kosmiczna pustka, człowiek musi przynajmniej próbować zapanować - postacie Myśliwskiego czynią to, wiążąc się z otaczającą przestrzenią, z reguły daną, a nie wybraną, uznaną za własną wbrew niesprzyjającym okolicznościom czy dotkliwym niewygodom.

Zarażonemu chaosem i erozją światu bohaterowie narzucają porządek własnej opowieści - rozwijanej wedle założonego planu, a proces ten odbywa się na wszystkich piętrach i płaszczyznach przekazu. To samo przecież czynił Myśliwski-autor od pierwszego napisanego utworu, a w miarę upływu lat doskonalił tę umiejętność, wypracowując jednocześnie swój rozpoznawalny, nośny artystycznie styl. Twórczość Myśliwskiego w czasach PRL-u rozwijała się poniekąd z dala od głównego nurtu prozy, choć wpisywała się w jej porządki. Pisarz debiutował późno, dopiero w roku 1967, kiedy ukończony trzydziesty rok życia miał dawno za sobą - dlatego jego wczesne utwory nie miały charakteru juweniliów. Od początku w tworzonych przez niego powieściach istotną rolę odgrywała przemyślana kompozycja, dopracowane formy narracyjne, a świat przedstawiony poddawany był rozbudowanej metaforyzacji. Tematem głównym pisarstwa Myśliwskiego wydaje się kategoria trwania, często ukazywana poprzez swą opozycyjną odsłonę, ucieczkę (bezcelową i nieskuteczną) oraz problematyka przymusu istnienia w świecie - na przekór wszelkim przeciwnościom losu.

\footnotetext{
3 T. Sławek, Być z przestrzeniqa, „Autoportret” 2013, nr 2 (41), s. 5.
} 
Utwór Nagi sad, którym pisarz zadebiutował ${ }^{4}$, wpisany został w nurt chłopski, pojmowany jako dawanie świadectwa przemianom chłopskiego losu, łączącego się z problematyką awansu społecznego, choć Myśliwski stworzył opowieść o awansie niechcianym. W pierwszoosobowej narracji bohater opowiadał o wykorzenieniu z wiejskiej przestrzeni, z którą nie mógł się do końca utożsamić odkąd po naukach w mieście został nauczycielem. Jest to też afabularna opowieść o ojcu, podporządkowana regule ożywiania przeszłości w jej ustabilizowanych/uświęconych przez tradycję obrazach. Narracja posłużyła odtworzeniu biografii, ukazanej w perspektywie relacji między ojcem a synem - ojcem, który wymyślił los syna. Świat Nagiego sadu, to świat zawierający się w jednostkowej świadomości. Poszukiwanie tożsamości przez syna, dążenie do prawdy prywatnej, naznaczonej subiektywnością wpisywało się nadto w procesy przemian polskiej prozy po roku 1956. Jednak już w pierwszej powieści Myśliwskiego zwracał uwagę wysiłek aksjologicznego porządkowania przestrzeni.

Literatura nurtu chłopskiego obrazowała rozdwojenie tożsamości - bohaterowie na różne sposoby radzili sobie z rozdarciem między tradycyjnymi wzorcami zamkniętej wiejskiej społeczności a możliwościami egzystencji w otwartym świecie zewnętrznym. W przypadku Syna z Nagiego sadu sfera miejskiego awansu okazała się niechcianym darem od Ojca. Ostatecznie to rodzinna wieś, domostwo i znajdujący się w jego granicach sad stały się dla bohatera jedynym waloryzowanym pozytywnie miejscem. Rola wiejskiego nauczyciela umożliwiła mu (częściowo przynajmniej) zacieranie piętna obcości, jakim został naznaczony przez gromadę po powrocie z miasta - pozostawał na obrzeżach swojej społeczności, ale mógł odczuwać przynależność do świata ojcowskiej tradycji.

Powstała na początku ósmej dekady ${ }^{5}$ druga powieść, zatytułowana $P a-$ łac, to także zapis doświadczenia jednostkowego, które tym razem jednak nie rozgrywa się $\mathrm{w}$ przestrzeni całej biografii, lecz jednego przełomowego dnia życia. Do opuszczonego po przejściu wojennego frontu pałacu wkracza owczarz Jakub i na jeden dzień bierze pałac w posiadanie. Monolog głównego bohatera ukazuje proces dojrzewania chłopa do przyjęcia roli pana. Jakub wciela się $\mathrm{w}$ pana możnego, okrutnego, w bezwzględnego prawodawcę podległych mu istot, a przyjmując tę rolę odkrywa ciemną stronę swojej natury. Podświadomość zbiorowa, wspólnotowe mity i symbole sprawiają, iż realizowany przez owczarza los pana jest odtwarzaniem stereo-

4 W. Myśliwski, Nagi sad, Warszawa 1967.

5 W. Myśliwski, Pałac, Warszawa 1970. 
typów zbudowanych na opozycji pańskości i chłopskości. W trakcie tych działań Jakub dowiaduje się, kim jest, zdobywa niezależną podmiotowość po to, by dokonać świadomego wyboru losu - śmierci w pożarze, który niszczy pałac.

Przestrzeń pańskiego dworu, opuszczonego i pozostawionego na pastwę żywiołów historii, nie mogła stać się dla Jakuba własną na dłużej niż kilka godzin, które można uznać za martwy punkt czasu. Finałowy pożar to nie tylko wizja destrukcji starego porządku, to zarazem gest autodestrukcji bohatera, który nie potrafi przekroczyć dualnego (chłopsko-pańskiego) oglądu świata. Owczarz nie miałby szans odnaleźć się w nowej rzeczywistości, dlatego wybiera śmierć pod gruzami starej. Opis rozpadu znanego świata, tradycyjnych porządków oraz podstaw wspólnotowej egzystencji, rozpadu, któremu przeciwstawić można jedynie indywidualny wysiłek scalania potrzaskanych sensów w tworzonej na własny użytek opowieści, wykrystalizował się wówczas jako oś pisarstwa Myśliwskiego.

Pomimo upływu lat od pierwszego wydania najbardziej interesującą powieścią Myśliwskiego wydaje się trzecia z nich, Kamień na kamieniu. Wydana $\mathrm{w}$ pierwszej połowie lat osiemdziesiątych ${ }^{6}$ trafiła $\mathrm{w}$ komunikacyjną rzeczywistość, w której nie było na nią powszechnego zapotrzebowania. Miała stać się dopełnieniem chłopskiej trylogii, a nawet zamknięciem całego nurtu chłopskiego - tak zresztą bywa postrzegana i dziś. Jednocześnie jednak okazała się początkiem nowej tetralogii - wyrastającej z chłopskiej tradycji, ale ją przekraczającej i uniwersalizującej, służącej jednocześnie mityzacji i demityzacji ginącego bezpowrotnie świata. Było to także swoiste uprawomocnienie eskapizmu - w ramach którego nie jest możliwe odtworzenie utraconych sensów rzeczywistości, ale $\mathrm{w}$ zasięgu pozostają próby przywrócenia jej sakralnego wymiaru ${ }^{7}$.

Niechronologiczna opowieść tworzona z punktu unieruchomionego w czasie odtwarza biografię Szymona Pietruszki, jedynego bohatera Myśliwskiego obdarzonego imieniem i nazwiskiem, o dookreślonym życiorysie i statusie. Jednocześnie - $\mathrm{i}$ to właśnie podnosi rangę utworu - to narrator niewiarygodny, a kreowanie przez niego obrazu świata i siebie nie pozwala ukryć prawdziwej, skomplikowanej i trudnej do zaakceptowania, natury Szymona. W świecie przedstawionym rozpad mitów zbiorowych w sposób ostateczny uniemożliwiał wykreowanie mitu prywatnego - pozostały autoterapeutyczne

6 W. Myśliwski, Kamień na kamieniu, Warszawa 1984.

7 Zob. B. Kaniewska, Mityzacja eskapizmu (Kamień na kamieniu Wiesława Myśliwskiego), w tejże: Świat w granicach "ja". O narracji pierwszoosobowej, Poznań 1997. 
próby jego stworzenia ${ }^{8}$. Czytelnik natomiast zyskał możliwość aktywnego uczestniczenia $\mathrm{w}$ dookreślaniu biografii bohatera, oraz podejmowania decyzji w sferze wartościowania. Od tego, w jaki sposób scalił podmiotowość Szymona, zależały bowiem granice ofiarowanej mu empatii lub potępienia. Nadto demaskowanie okrutnych reguł rządzących rozwarstwiającą się przestrzenią doświadczenia biograficznego pozwalało ukazać decyzję trudnego powrotu do (ograniczonego, traktowanego wybiórczo) zbioru tradycyjnych wartości jako jednostkowy wysiłek bohatera, czyniony wbrew niesprzyjającym warunkom zewnętrznym.

Kolejny utwór Widnokrąg, był jedną z najbardziej wyczekiwanych po przełomie 1989 roku powieści ${ }^{9}$ - miał stać się epickim podsumowaniem PRL-u. Tymczasem czytelnicy otrzymali najbardziej przesyconą elementami autobiograficznymi opowieść o dojrzewaniu i zakorzenianiu w bycie, w której realiów minionej epoki było w istocie niewiele. Myśliwski Widnokręgiem późno i jednorazowo wpisał się w nurt „małych ojczyzn”, w jego niemal klasycznej odmianie. Podobnie jednorazowo, choć w zgodzie z obowiązującymi tendencjami, wpisał się w nurt prozy inicjacyjnej, wyraziste zjawisko lat dziewięćdziesiątych, służące ponownemu opisaniu świata, jego reinterpretowaniu, pozbawionemu balastu uprzedniej wiedzy. Każdy z rozdziałów (zgodnie z metodą wypracowaną w Kamieniu na kamieniu) tworzył osobną opowieść obudowaną wokól jednego zdarzenia, którego zakończenie zostało już dane uprzednio. W tym przypadku afabularność wspierana pracą pamięci pozwalała jednak dokładniej odtwarzać osobisty ogląd przeszłości oraz odzyskiwać jej jednostkowy wymiar ${ }^{10}$, na przekór zestereotypizowanym wzorcom wielkich narracji historycznych.

Rozpoznawalne w tekście, choć niewymienione z nazwy miasto - Sandomierz - stało się z pozoru specyficznym centrum świata młodego człowieka, punktem, z którego postrzega się widnokrąg, miejscem odtwarzanym z niezwykłą pieczołowitością i emocjonalnym zaangażowaniem. Jednak uważna lektura pozwala ustalić inny porządek biografii głównego bohatera. W kolejnym starciu „miejskości” z chłopską tradycją znów wygrywa zmityzowane trwanie w wiejskiej społeczności. Ostatecznie to wieś dziadków Piotra (oraz groby przodków na miejscowym cmentarzu) staje się dla niego najważniej-

\footnotetext{
8 Zob. A. Czyżak, Uniwersum w okruchach, w tejże: Życiorysy polskie 1944-89, Poznań 1997.

9 W. Myśliwski, Widnokrag, Warszawa 1996.

$10 \mathrm{~W}$ tej perspektywie istotne wydają się deklaracje Myśliwskiego, że nadrzędnym tematem Widnokręgu jest miłość Piotra i Anny oraz że wątek ten - choć zaledwie naszkicowany - stał się głównym powodem napisania utworu (zob. H. Zaworska, Dobrze, że żyłem. Wywiady z pisarzami, Warszawa 2002).
} 
szym miejscem biografii, osią świata. W Widnokręgu zresztą rozgraniczenie obu rzeczywistości zyskuje wymiar niejako „namacalny" - w wizji stromych schodów prowadzących z podmiejskiego, nędznego osiedla Rybitwy do centrum Sandomierza:

Te schody zaczynały się za naszym domem i prawie w linii prostej, z niewielkimi odchyleniami w jedną, drugą stronę, poprzerywane brukowanymi podestami co kilkanaście stopni, pięły się na sam szczyt wzgórza, na którym leżało miasto. Lub odwrotnie, jako że wszystko zależy od naszego miejsca w przestrzeni, przestrzeń bowiem określa nasze odczucia i wyobrażenia, a w konsekwencji nasz los, zaczynały się na szczycie tego wzgórza, na którym leżało miasto, i spadały kaskadą po najbardziej urwistej jego stronie aż do miejsca, gdzie brała swój początek ta rozległa równina ${ }^{11}$.

Dla bohatera, który wielokrotnie wspinał się po tych właśnie schodach, by dotrzeć do centrum miasta (także w towarzystwie chorego ojca, dla którego stawały się "Golgotą"), były swoistą granicą między przestrzenią oswojoną, bliską, zrozumiałą a nieprzyjaznym obcym światem, rządzącym się własnymi prawami, a na dodatek rządzonym przez prawodawców nowego, opresyjnego systemu.

W następnym obszernym utworze, Traktacie o tuskaniu fasoli, tytułowa traktatowość dzieła stała się ujawnianą świadomością warsztatową ${ }^{12}$. Mono$\log$ wypowiadany przez anonimowego bohatera do anonimowego słuchacza - obaj są zresztą istotami o niepewnym statusie ontycznym - to zarazem seria argumentów, które miały dowodzić tezy, iż los jednostek jest zdeterminowany przez historię. Epicka panorama została ponownie zastąpiona przez perspektywę losów pojedynczego człowieka. Kolejny „raport antropologiczny" dotyczący codzienności w „nieludzkim czasie” został znów oparty na konstrukcji biograficznej. Tym razem ziemska wędrówka bohatera zatoczyła koło: wyrzucony w dzieciństwie ze swojej rodzinnej wioski przez dziejowy kataklizm, tułał się przez całe dorosłe życie po świecie, by na starość wrócić do miejsca narodzin i opiekować się samotnie grobami utraconych bliskich.

W Traktacie o tuskaniu fasoli jednak najwyraźniej widać, iż dla Myśliwskiego Historia to zarazem zbiór faktów, kształtowany wciąż od nowa model dziejów oraz impuls czy nawet przymus do tworzenia historiozoficznych uogólnień. Zawsze ukazywana jest przez pryzmat doświadczenia egzystencjalnego, którego artykulacja jest możliwa jedynie w słowie. Przebieg bio-

11 W. Myśliwski, Widnokrąg, s. 28.

12 W. Myśliwski, Traktat o łuskaniu fasoli, Warszawa 2006. 
grafii bohaterów Myśliwski ukazuje w przestrzeni, której ukonkretnianie, w miarę rozwoju jego drogi twórczej, w coraz większym stopniu zależy od odbiorcy. Tym samym realia pozostają podwójnie determinowane - nie tylko kształtem narracji, retoryczną strategią, kompozycją, stylistyką, zależą także od wrażliwości, wiedzy, otwartości czytelnika. Zawsze też są relatywizowane wobec podmiotu narracji, gospodarza opowieści: człowieka w świecie. Traktat o łuskaniu fasoli ukazuje $\mathrm{w}$ istocie niemożność odróżnienia doświadczenia narracyjnego od historycznego i egzystencjalnego.

Ostatnie rozdanie to na razie "ostatnia", kończąca proces literackiego odsłaniania i rozpoznawania kondycji świata i człowieka po wielkiej katastrofie, odsłona twórczości Wiesława Myśliwskiego. Pomyślana jako swoista summa dotychczasowych dokonań stała się powtórzeniem, ale i przetworzeniem wcześniej podejmowanych tematów i wątków. Konstrukcja przestrzeni znów uzyskała wymiar metaforyczny - „człowiek w świecie” usytuowany pomiędzy koniecznością podejmowania walki z losem a możliwością dokonywania wyborów kształtujących egzystencję, musi odnajdywać (ustanawiać) na własny użytek porządek istnienia. Pojawiające się głosy krytyczne, sugerujące, iż Ostatnie rozdanie jest prostą kontynuacją poprzedniej powieści, ufundowane zostały na podobieństwie chwytów narracyjnych. Istotniejsza jednak wydaje się zmiana perspektywy oglądu świata, tym razem dokonywana $\mathrm{z}$ punktu widzenia człowieka niezakorzenionego, a nawet odrzucającego ideę trwania w wybranym, uznanym za własne miejscu.

Narrator często deklaruje swój związek z rzeczami, czy nawet swoistą podległość wobec materialnych składników codzienności:

i te najzwyklejsze, codzienne porządki właśnie przez codzienną powtarzalność wyrabiają w nas rytm, który to rytm kieruje nami, jakby poza naszą wolą, chęcią i pamięcią, tak że wydawałoby się, nic to nas już nie kosztuje. A jednak zdarza się, że nieoczekiwanie doznajemy dziwnego zakłócenia owego rytmu i zaczynamy odczuwać trudną do przezwyciężenia udrękę [s. 20].

Porządkowanie rzeczy niesie jednak ze sobą ryzyko, tym większe im mniej stabilna okazuje się sytuacja egzystencjalna człowieka, im mniej poczucia bezpieczeństwa daje mu przestrzeń jego codziennych zmagań. Bohater porządkować może jedynie chwilowe miejsca postoju, przystanki na drodze nieustającej tułaczki. Tym samym „porządkowanie” notesu z adresami uznać można za czynność zastępczą, kompensacyjną wobec poczucia bezdomności.

Brak akceptacji dla istnienia (trwania w wybranym/danym miejscu) częstokroć okazuje się pochodną braku samoakceptacji. Bohater Ostatniego rozdania mówi wprost: 
wszystkie tęsknoty, jakie mnie nachodziły, wydawały mi się tęsknotami nienawidzącymi. I nie świata, ludzi, życia, lecz samego siebie [...] wtedy, gdy wróciłem po rzuceniu studiów do domu, czułem się jakby obumarły i chwilami było mi wszystko jedno, czy zostanę krawcem, czy kimkolwiek, czy nikim [s. 111].

W jego przypadku niezdolność zatrzymania się w jednym miejscu na dłużej okazywała się $\mathrm{w}$ istocie niezdolnością pogodzenia się z powtarzalnymi rytuałami codzienności. Wobec rodzinnego miasta odczuwał nie tyle dystans, co żywiołową niechęć - powtarzał wielokrotnie: „nie wyobrażałem sobie, że mógłbym spędzić tutaj życie, nienawidziłem tego naszego miasteczka. Nawet dom matki stał mi się obcy, jakbym był jednym z tych gości, który przyjechał na dwa, trzy dni, lecz zaraz wyjedzie" [s. 107]. Jednocześnie każde kolejne miejsce, miasto, wieś, napotykane po drodze okazywało się przestrzenią, której nie można oswoić, a jedynie przebywać w niej „przejazdem”, przez krótką chwilę, bez zobowiązań i zależności.

Ten sam mechanizm zadziałał w momencie, gdy sytuacja bohatera zmierzała do typowej rodzinnej stabilizacji - co doprowadziło ostatecznie do utraty jedynej prawdziwej miłości:

nie umiałem sobie wyobrazić, że mógłbym $\mathrm{w}$ tym mieszkaniu $\mathrm{w}$ przyszłości zamieszkać, gdybyśmy się pobrali z Marią [...] Może już wówczas odezwała się we mnie ta chyba wrodzona niechęć do przywiązywania się do jakichkolwiek miejsc i w ogóle do przywiązywania się do czegokolwiek [s. 167].

Jedynym wyjściem okazało się zamieszkanie w świecie i podjęcie egzystencji w poszerzonej przestrzeni nieustannej wędrówki. Wędrowanie - bez końca i bez wytchnienia - ułatwiało prześlizgiwanie się po powierzchni świata i umożliwiało ucieczkę od siebie. Bohater przekonał się o tym boleśnie, gdy po złamaniu nogi został na dłużej unieruchomiony w kolejnym przygodnym miejscu pobytu.

Uwięzienie $\mathrm{w}$ jednym punkcie przestrzeni ukazało bezbronność bohatera wobec świata, nieprawdziwość jego złudzeń wobec siebie i własnej relacji z przestrzenią. Zapragnął wówczas - znów za pomocą notesu - znaleźć klucz do swojego życia, choć nie zastanawiał się nad tym, co tak naprawdę nim otworzy. Mówił jednak, wyrażając tym samym wewnętrzny sprzeciw wobec czynności narzuconej przez zrządzenie losu:

czy to nie ironia, że życie biegnące dotąd i tak, i siak, wzdłuż, w poprzek, w górę, w dól, poganiane przez upływający czas, zostało nagle zmuszone do zatrzymania się przez najzwyklejszy przypadek [...] Śmieszne, żeby coś takiego, co przydarza się milionom ludzi łamiącym nogi, mogło mieć aż taki wpływ na człowieka, że chcąc nie chcąc, przenosi wzrok ze świata w siebie [s. 303]. 
Wzrok zwrócony do wewnątrz nie wydobył odpowiedzi mogących zmienić trajektorię zatrzymanej na pewien czas podróży - pomógł jednak uświadomić reguły godzenia się $\mathrm{z}$ losem, takie same, niezależnie od tego, czy człowiek wybiera osiadły, czy też wędrowny tryb życia.

Jeden $\mathrm{z}$ małomiasteczkowych, nieuczonych mędrców, jakich wielu w prozie Myśliwskiego, stary szewc Mateja, z którym bohater grał w karty podczas każdej wizyty w rodzinnej miejscowości, często i głośno wyrażał tę powszechną, $\mathrm{w}$ istocie konsolacyjną zgodę na warunki, w których przyszło mu egzystować - akceptacja przymusu trwania w najgorszych nawet okolicznościach rodzi się bowiem z gorzkiej wiedzy o braku prawdziwego wyboru. Mówił o otaczającym go świecie: "Ale tak jak w butach musi się chodzić, tak się musi żyć na takim, jaki jest. Nie wymyślono by tamtego, gdyby na tym dało się sprawiedliwie. Ale $\mathrm{w}$ tamten nie wierzę, to muszę wierzyć, że ten da się naprawić" [s. 322]. Trudno jednak w takiej sytuacji o egzystencjalne poczucie spełnienia, pozostaje raczej godzić się ze stoicką rezygnacją na konieczność podejmowania nieustannej walki z przeciwnościami losu. Tym samym dojrzewanie do narracyjnej (kompensacyjnej i autoterapeutycznej) sprawności staje się równoznaczne z trudem wypracowywaną (paradoksalną) akceptacją dla własnego istnienia w stanie permanentnego buntu wobec reguł rządzących światem.

Bohater Ostatniego rozdania również uznawał przygodność bytu za jego regułę - zawsze jednak (podobnie jak pozostali protagoniści Myśliwskiego) przeciwstawiał jej swobodę wyboru zasad porządkowania świata w tworzonych na własny użytek opowieściach. Bogumiła Kaniewska pisała w podsumowaniu swoich rozważań o twórczości Myśliwskiego:

Impuls snucia opowieści, jaką realizują narratorzy Myśliwskiego, wynika każdorazowo ze sprzeciwu wobec kształtu świata, praw rzeczywistości, miejsca i czasu, z potrzeby zarysowania własnego widnokręgu tak, by móc zadomowić się $\mathrm{w}$ świecie nawet wbrew niemu samemu. $\mathrm{W}$ chaosie, rozproszeniu, poczuciu utraty, samotności wszyscy oni będą poszukiwać ładu, całości, powrotu, wspólnoty ${ }^{13}$.

Bohater najnowszej powieści niezdolny do zakorzenienia się w miejscu tradycyjnie pojmowanym jako własne - bo bliskie, rodzinne, dobrze znane i oswojone - zmagać się musiał z wyzwaniem, jakie wiąże się z nomadycznym trybem trwania $w$ świecie. Poszerzył tym samym granice doświadczania przestrzeni, która stała się areną jego życiowych wyborów, lecz zysk okazał się pozorny.

13 B. Kaniewska, Opowiedziane. O prozie Wiesława Myśliwskiego, Poznań 2013, s. 209. 
Protagonista, dając świadectwo ponawianym wielokrotnie gestom nawiązywania chwilowych, ulotnych więzi z przygodnie i na krótko spotykanymi ludźmi, odsłaniał znów bolesną prawdę, iż największym złudzeniem człowieka okazuje się poczucie trwałości, stabilizacji, pewności dokonywanych wyborów. Tym samym diagnoza kondycji „człowieka w świecie” prowadzi do ontologicznego (choć nie epistemologicznego) pesymizmu, natomiast ów nadrzędny zamysł artystyczny przyjmuje ponownie ów specyficzny, dopracowywany z każdym kolejnym utworem, rozpoznawalny kształt narracyjny. Roch Sulima przekonywał, iż Wiesław Myśliwski „świadomie czyni swego opowiadacza nadzwyczaj aktywnym, a przy tym bardzo skrupulatnym rzecznikiem świata, po którym nas oprowadza", bowiem w efekcie odbiorca odnosi wrażenie, że narrator nieustannie "mierzy się z czymś niemożliwym do spełnienia, jakby chciał uwzględnić wszystkie możliwe punkty widzenia"14. Dodawał także:

Proza Myśliwskiego tak często powraca do słowa „świat”, jak powraca się do niego w potocznej rozmowie, kiedy wyczerpują się możliwości rozpoznania reguł sensu, kiedy siła, brutalność czy naoczność doświadczenia „zawiesza” moc naszych wyjaśnień i reguły rozpoznań, gdy naga egzystencja wymyka się kulturze. W obliczu sytuacji granicznych na świat "zdają się" zarówno filozofowie w swoich sylogizmach, jak i „maluczcy” w chwili zwątpienia, w potrzebie poczucia wzniosłości, w doświadczaniu rozpaczy ${ }^{15}$.

Świat zatem - niezależnie, czy ogranicza się do małej wioski, skupiska letniskowych domków, miasteczka, miasta, kraju czy kontynentu - to dana człowiekowi jedyna przestrzeń, zawsze ograniczona widnokręgiem. Zarazem jest to przestrzeń, w której egzystencja jednostki determinowana jest przez siły od niej niezależne, brutalnie ingerujące $\mathrm{w}$ przebieg biografii, ograniczające swobodę wyboru, utrudniające samopoznanie.

Trwanie bohaterów Myśliwskiego w przestrzeni pozostaje niezmiennie sumą wyzwań - trzeba im sprostać w miarę ograniczonych możliwości kształtowania własnego losu. Jedną z niezbędnych umiejętności okazuje się tym samym zdolność nawiązywania osobistych, jednostkowych relacji z przestrzenią, wykraczających poza rutynową, a przede wszystkim bezrefleksyjną wegetację. Tadeusz Sławek przekonywał:

Autentyczność naszego życia zależy w podstawowym stopniu od naszej wrażliwości na przestrzeń. To zaś oznacza nic innego jak wyzwolenie codzienności

14 R. Sulima, Życie podług słowa. O metodzie prozy Wiesława Myśliwskiego, „Akcent” 2017, nr 2 (148), s. 39.

15 Tamże, s. 38. 
spod władzy percepcyjnej rutyny, a tym samym oswobodzeniu jej z dotychczasowego stanu rzeczy. Ostatnią syntagmę musimy traktować jak najdosłowniej: doświadczać przestrzeni oznacza doświadczać rzeczy i miejsc w ten sposób, że to, co przedstawia się nam jako „ważne” okazuje się nieistotne ${ }^{16}$.

Przestrzeń nabiera wymiaru egzystencjalnego, gdy pozostaje z nami w żywej relacji - a pozostawać może wówczas, gdy opowiadamy ją (sobie) wciąż od nowa, otwierając się także na jej nieoczywiste czy nie rozpoznawane powszechnie wyzwania.

Syn z Nagiego sadu, owczarz Jakub, Szymon czy narratorzy kolejnych powieści Myśliwskiego wiodą egzystencję w świecie, którego prawa i porządki budzą sprzeciw, którego bezprawie i nieporządek okazują swą przemożną siłę - tylko ujmowanie doświadczenia biograficznego w opowieść pozwala na niechętne, niełatwe, warunkowe godzenie się z ludzkim przeznaczeniem. Natomiast tekstowe porządkowanie ich biograficznych przestrzeni każdorazowo pozwala dookreślać kolejny wariant opowieści o „byciu w świecie” oraz osadzać w realiach kolejną odsłonę autorskiej diagnozy kondycji człowieka we współczesności.

\section{Bibliografia}

Czyżak Agnieszka, Życiorysy polskie 1944-1989, Poznań: Wydawnictwo „Poznańskich Studiów Polonistycznych", 1997.

Kaniewska Bogumiła, Świat w granicach "ja". O narracji pierwszoosobowej, Poznań: Rebis, 1997.

Kaniewska Bogumiła, Opowiedziane. O prozie Wiesława Myśliwskiego, Poznań: Wydawnictwo Naukowe UAM, 2013.

Myśliwski Wiesław, Nagi sad, Warszawa: PIW, 1967.

Myśliwski Wiesław, Pałac, Warszawa: PIW, 1970.

Myśliwski Wiesław, Kamień na kamieniu, Warszawa: PIW, 1984.

Myśliwski Wiesław, Widnokrąg, Warszawa: Muza S.A., 1996.

Myśliwski Wiesław, Traktat o łuskaniu fasoli, Kraków: Znak, 2006.

Myśliwski Wiesław, Ostatnie rozdanie, Kraków: Znak, 2013.

Rybicka Elżbieta, Geopoetyka: konstelacja i światowanie, w: Przestrzeń - literatura - doświadczenie. Z inspiracji geopoetyki, red. T. Gęsina, Z. Kadłubek, Katowice: Wydawnictwo Uniwersytetu Śląskiego, 2016, s. 9-12.

Sławek Tadeusz, Być z przestrzeniq, „Autoportret” 2013, nr 2 (41), s. 5-11.

Sulima Roch, Życie podług słowa. O metodzie prozy Wiesława Myśliwskiego, "Akcent” 2017, nr 2, s. 34-46.

Zaworska Helena, Dobrze, że żyłem. Wywiady z pisarzami, Warszawa: Muza S.A., 2002.

16 T. Sławek, Być z przestrzenia, s. 5. 


\section{Arranging Biographical Spaces: Wiesław Myśliwski's Ostatnie Rozdanie \\ Summary}

The article offers the discussion of Wiesław Myśliwski's Ostatnie rozdanie, which is developed along two perspectives. One is the author's prosewriting, the other uses spatial aspect. Both perspectives depict the literary realm and the topographic representations of the main characters' biographies. Myśliwski's refined narrative style gradually evolves to become a vehicle for his pessimistic diagnosis of the human condition and our existence. Determined by historical, social and cultural factors, it invariably remains situated in the significantly arranged space.

Keywords: space, experience, biography, narration, Wiesław Myśliwski 